\title{
Relationship of Physical Fitness to Physical Education Learning Outcomes of Class VIII Students of Junior High School Negeri 6 Siak Hulu
}

\author{
Giant Rexy Nanda ${ }^{1 *}$, Merlina Sari ${ }^{2}$, and Rezki ${ }^{3}$ \\ ${ }^{1,2,3}$ Dep. of Teacher Training and Education, Riau Islamic University, Indonesia \\ "Corresponding author. Email: gianrexynanda@gmail.com
}

\begin{abstract}
Based on observations made by the authors of junior high school 6 Siak Hulu, where the desire of students to exercise is still felt to be very less than expected. Obstacles in practice in the field, where students are not active in the learning process, this is caused by the habits of students who do not understand the importance of health and fitness, so students are not accustomed to sports activities, and cause learning outcomes from physical education and sports students become less optimal. This type of research is correlational consisting of two variables, $\mathrm{X}$ physical fitness and learning outcomes $\mathrm{Y}$, this study aims to determine the relationship between physical fitness and physical education learning outcomes of students of class VIII of Junior High School Negeri 6 Siak Hulu, where the number of samples is 30 male students. Based on the results of data processing obtained by Rhitung of 0.046 classified as very low. While the T-test calculation was obtained hitung <ttabel or $0.24<2,048$. This means that the correlation of variable $\mathrm{X}$ with $\mathrm{Y}$ or the relationship of physical fitness with learning outcomes is not significant, so the proposed hypothesis is rejected.
\end{abstract}

Keywords: Physical fitness and learning outcomes

\section{INTRODUCTION}

Education is important for every human being, consciously or not since humans were born into the world have started to learn. Education is more an interaction between education and students. Education conducts educational activities, while students do learning activities. Physical Education is a medium to support the development of motor skills, physical abilities, knowledge, and reasoning. In addition, physical education is also a medium to encourage mental, emotional, spiritual, social, and healthy lifestyle attitudes that lead to stimulating balanced growth and development.

As stated in the Law of the Republic of Indonesia No.3 of 2005 Concerning National Sports Article 1 paragraph 13 which states that, "Achievement sports are sports that foster and develop athletes in a planned, persistent, and sustainable way through competencies to achieve achievements with the support of sportsman science and technology".

With the physical education subjects sports and health is one of the media to encourage physical growth, psychological development, motor skills, knowledge and reasoning, appreciation in attitudes, mental values, sportsmanship, spirituality, social, and habituation of healthy lifestyles that lead to to stimulate balanced physical and psychological quality growth and development.

Learning outcomes are a peak or an acquisition of value from the learning process. According to Dimyati and Mudjiono (2013: 3-4), the result of learning is the result of an intraction of learning and teaching, which in turn can be a change in cognitive, affective and psychomotor abilities, depending on the teaching. While the definition of learning outcomes according to Hamalik (2013: 30) states the learning outcomes are there changes in behavior in the person, the minute from not knowing to knowing and from not understanding to understanding.

Based on the above opinion it can be explained that learning is a process of change in a person. The result of learning is a change in various forms such as knowledge, experience, attitudes and behavior, skills, abilities, and so on. Factors that affect learning outcomes both internal factors and external factors influence the learning outcomes of students, especially in Physical Education and Sports subjects so that students can not achieve learning outcomes Physical Education and Health Physical education subjects if still influenced by factors the factors above. One of the most important factors influencing student learning outcomes in Physical Sports and Health Education subjects is the student's physical 
fitness level, because this is directly related to students in teaching and learning.

Activities carried out at school must be directed and planned, in order to achieve the desired physical fitness goals. One area of study that is quite important in the context of increasing physical fitness is the subject of physical education in sports and health. According to Widiastuti, (2017: 13) "Physical fitness is a physical condition that describes the potential and physical ability to perform certain tasks with optimal results without showing significant exhaustion". Physical fitness for students is needed in order to have a positive impact on its development, including learning activities which are currently a priority in education. Learning outcomes can be achieved with a maximum if supported by physical fitness that is fit and healthy. Thus the need for refreshment by exercising so that the level of physical fitness is maintained. Physical fitness is a determining factor in all human life, including student learning outcomes at school.

To get a good level of physical fitness, it is necessary to pay attention to several factors that can influence it. Arsil (2008: 12) several factors that can affect the level of good physical fitness include; "Work (physical activity), rest periods, descent, lifestyle, environmental conditions, habits, food". Furthermore Gusril (2004: 119) suggests factors that affect the level of physical fitness of students, among others: "type of work, health conditions, gender, age, level of student training, learning motivation and nutritional status".

Physical fitness for students is needed in order to have a positive impact on its development, including learning activities which are currently a priority in education. Learning outcomes can be achieved with a maximum if supported by fresh and healthy physical fitness. Thus the need for refreshment by exercising so that the level of physical fitness is maintained. Physical fitness is a determining factor in all human life, including student learning outcomes at school.

In Junior High School Negeri 6 Siak Hulu class VIII based on observations made by the author, where the desire of students to exercise is still felt very less than expected. The problem is the practice in the field, where students are not active in the learning process, this is due to the habits of students who do not understand the importance of health and fitness, besides that the motivation from students is still lacking due to students who are not accustomed to with sports activities. so many students complain (look tired) and ask to want to rest immediately when the subject matter has not been completed. There are also many students who are lazy to follow the material and prefer to do things that are outside the subject matter.
Based on the problems found at the research sites mentioned above, the thought arises to conduct research to uncover "Relationship of Physical Fitness To Physical Education Learning Outcomes of Class VIII Students of Junior High School Negeri 6 Siak Hulu".

\section{MATERIALS AND METHODS}

This research was conducted using a correlational research plan. Correlation is a statistical tool, which can be used to compare the measurement results of two different variables to determine the level of relationship between Arikunto variables, (2013: 131). In this study, the independent variable is physical fitness, and the dependent variable is the learning outcomes of Class VIII students of Junior High School Negeri 6 Siak Hulu. The population is the entire subject of Arikunto's research, (2006: 130). Meanwhile, according to Sutrisno Hadi (2004: 185) the population is a population that is entered for investigation, the population is limited so that the population or individuals who have at least the same nature. The population in this study were all eighth grade students of Junior High School 6 Siak Hulu, totaling 194 people.

The sample is part of the number and characteristics possessed by the population Arikunto, (2006: 134) "if the subject is less than 100 it is better to take all of them into a sample, but subjects more than 100 may be taken 10$15 \%$ or $20-25 \%$. The total population uses random sampling techniques. Therefore in this study, researchers took $15 \%$ of the subjects from the total population, amounting to 30 male students.

\section{Operational definition}

To avoid misperceptions about the title, there needs to be a separate explanation about the meaning and meaning of the title. The explanation is encapsulated in the affirmation of terms such as the following:

1. Physical fitness is usually said by the term physical fitness. physical fitness from a physiological point of view is the capacity to be able to adjust to tiring exercises and recover from the effects of these exercises. Physical fitness is the ability of a person to complete daily tasks without experiencing significant fatigue, and live a healthy life. Indonesian Physical Fitness Test (TKJI) aged 13-15 years consisting of :

a. Fast Running Test (Sprint 50 meters)

b. Body Lift Test (Pull Up 60 seconds).

c. Sitting Lying Test (Sit Up 60 seconds).

d. Vertical Jump Test.

e. Run Away Test (1000 meter run for sons).

2. Learning outcomes are the result of an intraction of learning and teaching, which in turn can be a change in cognitive, affective and psychomotor abilities, depending on the teaching. The learning outcomes 
instrument used the average value obtained from the value of the Midterm Examination or the Midterm Learning Evaluation Results Report (UTS Report Card) for PJOK subjects.

\section{RESULTS AND DISCUSSION}

This study was intended to determine the relationship of Physical Freshness To Physical Education Learning Outcomes of Class VIII Students of Junior High School Negeri 6 Siak Hulu.h

1. Physical Fitness Data of Class VIII Students of Junior High School Negeri 6 Siak Hulu.

Based on tests conducted on 30 people, data obtained from the physical fitness of students using TKJI tests. Based on the analysis, it can be explained that those who get grades between 11-12 are 7 people with a percentage of 23\% while students who score between 13-14 are as many as 7 people with a percentage of $23 \%$ while students who score between $15-16$ are as many as 10 people with a percentage of $33 \%$ while students who score between 17-18 are as many as 4 people with a percentage of $13 \%$ while students who score between 19 20 are as many as 2 people with a percentage of $7 \%$ while students who score between 21 and 22 are as many as 0 people with a percentage of $0 \%$.

2. Physical Education Learning Outcomes Data for Class VIII Students of Junior High School Negeri 6 Siak Hulu.

Student learning outcomes in this study are measurements with the report card grades of physical education subjects. Based on the analysis, it can be explained that those who score between $80-81$ are 3 people with a percentage of $10 \%$ while students who score between $82-83$ are 3 people with a percentage of $10 \%$ while students who score between $84-85$ are 7 people with the percentage of $23 \%$ while students who score between $86-87$ are as many as 6 people with a percentage of $20 \%$ while students who score between 88 and 89 are as many as 7 people with a percentage of 23\% while students who score between 90 and 91 are as many as 4 people with a percentage of $13 \%$.

\section{Data analysis}

Based on the results of data collection from physical fitness and learning outcomes, then processed according to statistical product moment techniques, followed by $\mathrm{T}$ Test to find out whether there is a relationship or correlation of the two variables which are the main issues in this thesis.

Based on calculations using the product moment, the Rhitung result is 0.046 . This value when seen in the correlation coefficient table is very low.
To test the hypothesis whether there is a relationship of physical fitness to learning outcomes, a T-test is performed. from the results of $\mathrm{T}$-test calculations obtained thitung <ttabel or $0.24<2,048$. This means that the correlation of variable $\mathrm{X}$ with $\mathrm{Y}$ or the relationship of physical fitness to learning outcomes is not significant, so the proposed hypothesis is rejected. With the rules of the examiner as follows: If thitung > ttabel then it is significant

If thitung <ttabel then it is not significant

While the magnitude of the contribution of physical fitness to the learning outcomes of VIII grade students of Junior High School Negeri 6 Siak Hulu was $0.21 \%$. Based on the above calculation, the physical fitness contribution towards physical education learning outcomes of Grade VIII students of SMP Negeri 6 Siak Hulu is $0.21 \%$. While the remaining $99.79 \%$ is influenced by other factors.

\section{Discussion}

From the description above, it can be interpreted that there is no significant relationship between physical fitness with the physical education learning outcomes of Grade VIII students of Junior High School 6 Siak Hulu. Students who have a good level of freshness especially have a good spirit in participating in physical education learning when compared to students who have a moderate level of physical fitness.

The magnitude of the relationship between physical fitness to learning outcomes shows insignificant results in this school sample. This means that there is a less significant relationship between physical fitness with learning outcomes. The lack of physical fitness links to learning outcomes occurs because of the many other factors that support learning outcomes such as motivation, interests, environment, and so on (Slameto, 2013: 54-72). Student interest in learning can affect student learning outcomes, because students who have less interest will affect learning outcomes. An environment that is less supportive can also affect learning outcomes. Besides students still lack high motivation towards the lesson so the learning outcomes are still not perfect. Student motivation will also be able to influence learning outcomes, especially motivation that comes from within students themselves.

\section{CONCLUSIONS AND SUGGESTION}

Based on the results of research conducted, a conclusion can be drawn as follows: There is no relationship between physical fitness with physical education learning outcomes of class VIII students of Junior High School Negeri 6 Siak Hulu. The lack of physical fitness links to learning outcomes occurs 
because of the many other factors that support learning outcomes such as motivation, interests, environment, and so on (Slameto, 2013: 54-72).

\section{Suggestion}

Based on the research results obtained, it can be put forward some suggestions as follows:

1. To students, in order to be able to develop physical fitness independently by doing sports that are carried out continuously and systematically so as to increase the value of the student's physical fitness.

2. To the teacher, teachers are expected to take approaches to students in terms of the application of sports theory so that students are better guided.

3. In writing this thesis there are still many shortcomings, therefore the authors hope that there are researchers who can continue this research in order to achieve good learning outcomes.

\section{REFERENCES}

[1] Achmad Rifa'i R. C dan Catharina Tri Anni. 2010. Psikologi Pendidikan. Semarang: UNNES Press.

[2] Arikunto, Suharsimi. 2006. Prosedur Penelitian Suatu Pendekatan Praktik, Jakarta : Rineka Cipta 2010. Prosedur Penelitian Suatu

Pendekatan Praktik, Jakarta : Rineka Cipta

[3] Arsil. 2008. Pembinaan Kondisi Fisik. Padang : Universitas Negeri Padang.

[4] Depdiknas, 1999. Tes Kesegaran Jasmani Indonesia Pusat Kesegaran Jasmani dan Rekreasi Anak Umur 1315 Tahun. Jakarta : Depdiknas

[5] Depdiknas, 2000. Pedoman dan Modul Pelatihan Kesehatan Olahraga Bagi Pelatih Olahragawan Pelajar. Jakarta : Depdiknas

[6] Dimyati \& Mudjiono, 2013. Belajar dan Pembelajaran. Jakarta : Rineka Cipta

[7] Djoko, Pekik. $2004.2 \quad$ Pedoman Praktis Berolahraga untuk Kebugaran dan Kesehatan.Yogyakarta: Andi Offset.
[8] H. Y. S. Santoso G. Dan Dikdik Zafar S. 2012. Ilmu Faal Olahraga. (Fisiologi Olahraga). Bandung: PT Remaja Rosda Karya.

[9] Hamalik, O. 2011. Proses Belajar Mengajar. Jakarta : PT Bumi aksara.

[10] Ismaryati. 2008. Tes dan pengukuran Olahraga. Surakarta. UNS Press.

[11] Kusumawati, Mia. 2015. Penelitian Pendidikan Pejasorkes (Pedidikan Jasmani dan Kesehatan). Bandung : Alfabeta.

[12] M. Sajoto. 1988. Pembinaan Kondisi Fisik dalam Olahraga. Jakarta: Deparrteman Pendidikan dan Kebudayaan Direktorat Jendral Pendidikan Tinggi.

[13] Mangoenprasodjo, Setiono. 2005. Olahraga Tanpa Terpaksa. Yogyakarta: Thinkfresh.

[14] Muhibbin, Syah. 2000. Psikologi Pendidikan dengan Suatu Pendekatan baru. Bandung: PT. Remaja Rosdakarya.

[15] Nurhasan. 2001. Tes dan Pengukuran dalam Pendidikan Jasmani : Prinsip-prinsip dan Penerapannya. Jakarta : Directorat Jendral Olahraga, Depdiknas.

[16] Riduwan dan Sunarto, 2013. Pengantar Statistik. Bandung : Alfabeta.

[17] Sharkey, B.J. 2003. Fitness And Health. Alih bahasa Kebugaran dan Kesehatan oleh: Eri Desmarini Nasution. Jakarta: PT. Raja

[18] Slameto. 2013. Belajar dan Faktor-faktor yang Mempengaruhi. Jakarta : Rinika Cipta.

[19] Sugiyono, 2016. Metode Peneletian Kuantitatif, Kualitatif dan $R \& D$. Bandung Alfabeta.

[20] Syafruddin. 2011. Ilmu Kepelatihan Olahraga tTeori dan Aplikasinya dalam pembinaan Olahraga. Padang : UNP Press.

[21] Undang-undang Republik Indonesia Nomor 3 Tahun 2005 Tentang system Keolahragaan Nasional. [22] Widyastuti. 2011. Tes dan Pengukuran Olahraga. Jakarta : PT Bumi Timur Jaya 